\title{
Heterobasidion annosum and $H$. parviporum in the Southern Rocky Mountains and Adjoining States
}

James J. Worrall, Rocky Mountain Region, United States Department of Agriculture (USDA) Forest Service, Gunnison, CO 81230; Thomas C. Harrington, Department of Plant Pathology, Iowa State University, Ames 50011; James T. Blodgett, Rocky Mountain Region, USDA Forest Service, Rapid City, SD 57702; David A. Conklin, Southwestern Region, USDA Forest Service, Albuquerque, NM 87102; and Mary Lou Fairweather, Southwestern Region, USDA Forest Service, Flagstaff, AZ 86001

\begin{abstract}
Worrall, J. J., Harrington, T. C., Blodgett, J. T., Conklin, D. A., and Fairweather, M. L. 2010. Heterobasidion annosum and H. parviporum in the southern Rocky Mountains and adjoining states. Plant Dis. 94:115-118.

Collections of Heterobasidion spp. from Nebraska, Colorado, Arizona, and New Mexico were identified based on the sequence of the internal transcribed spacer region of the ribosomal DNA. The North American variant of Heterobasidion annosum sensu stricto was found on Pinus ponderosa and Juniperus virginiana in central Nebraska, southern Colorado, central Arizona, and southern New Mexico. The North American variant of H. parviporum was found on Abies concolor and Picea engelmannii in southern Colorado and central New Mexico. The pathogens were not found in a survey of conifer forests in Wyoming and the Black Hills of South Dakota. Historical records of annosus root disease are reviewed by host group to gain more insight into the potential distributions of the respective pathogens. An apparent lack of overlap in host range suggests that substitution of tree species may be a useful management approach in some cases.
\end{abstract}

Annosus root disease is caused by Heterobasidion annosum (Fr.) Bref. sensu lato. This fungus has been divided into several species that differ in morphology, ecology, intersterility, and molecular characters (16). In North America, two hostspecialized forms have been identified $(5,6,14,24)$ : a North American variant of $H$. annosum sensu stricto (also known as $\mathrm{P}$ type; referred to hereinafter simply as $H$. annosum), primarily on Pinus spp., and a North American variant of $H$. parviporum Niemelä \& Korhonen (also known as $\mathrm{S}$ type), primarily on Abies and Picea spp. $(5,14)$. Records of $H$. annosum sensu lato in the southern Rocky Mountains and adjoining states predate recognition of the respective Heterobasidion spp. We collected and identified the fungus from these areas to determine what species are present and their geographical and host ranges.

\section{MATERIALS AND METHODS}

The geographic scope of our study was coniferous forests of Wyoming, South Dakota, Nebraska, Colorado, Arizona, and New Mexico. Based on previous studies

Corresponding author: J. Worrall

E-mail: jworrall@fs.fed.us

Accepted for publication 30 September 2009.

doi:10.1094/PDIS-94-1-0115

This article is in the public domain and not copyrightable. It may be freely reprinted with customary crediting of the source. The American Phytopathological Society, 2010. that have characterized the distribution of root diseases over much of the area $(4,7,9-$ $12,15,23)$, we looked primarily where annosus root disease is known to occur. However, Wyoming and the Black Hills of South Dakota have not been extensively surveyed; therefore, we surveyed systematically in 231 conifer stands in Wyoming and 32 stands in the Black Hills. Trees in pockets of mortality and uprooted or snapped trees were examined for basidiomes of the pathogen and wood decay characteristic of annosus root disease. One isolate was obtained from a fire-killed tree as part of an unrelated study. Where the disease was encountered, basidiomes or decayed roots were collected. In most cases, pure cultures were obtained from infected roots or basidiomes but, in three cases, basidiome tissue was used directly for DNA extraction.

Template DNA for polymerase chain reaction (PCR) was extracted from cultures grown on malt extract agar or from portions of the hymenophore of basidiomes collected in the field. The extraction of DNA utilized the Prepman Ultra kit (Applied Biosystems, Foster City, CA). The internal transcribed spacer region (ITS) of the ribosomal (r)DNA was amplified using primers ITS1-F and ITS4 or ITS4B $(2,22)$. The PCR products were purified using QIAquick PCR Purification Kit (QIAGEN Inc.) and sequenced using the PCR primers at the DNA Sequencing and Synthesis Facility at Iowa State University.

Sequences were visually aligned with those of other Heterobasidion spp. (5) and analyzed using heuristic searches in PAUP 4.0 , with stepwise additions (simple) and tree-bisection reconnection (20). Gaps were coded as a new state (fifth character) because the gaps were consistently found within species and, except for outgroup taxa, most gaps were only one or two bases in length. Bootstrapping (100 bootstrap replicates) was used to determine confidence in the branches.

\section{RESULTS}

Of 18 collections, 7 were identified as the North American variant of $H$. annosum (American P type) and 11 as the North American variant of $H$. parviporum based on ITS sequencing (Table 1). Representative ITS sequences of these species and other Heterobasidion spp. were deposited in GenBank (accession numbers GQ162420 to GQ162432).

The seven collections from Pinus or $J u$ niperus spp. had identical ITS sequences, which matched the sequence of a previously studied (5) isolate from Pinus resinosa in New Hampshire and another isolate from $P$. ponderosa in California (Fig. 1 ), and the newly studied isolates differed by only one base from the ITS sequence of another $P$. ponderosa isolate from Montana. The Pinus isolates were earlier determined to be the American P type of $H$. annosum based on partial interfertility with European isolates of $H$. annosum, ITS and IGS rDNA sequences, and sequences of manganese peroxidase genes $(5,6,14)$. The bootstrap value for the branch connecting isolates of $H$. annosum was $99 \%$.

$H$. annosum was found on $P$. ponderosa and on one Juniperus virginiana in a disease center of $P$. banksiana. This form of the pathogen was found in New Mexico, Arizona, southern Colorado, and Nebraska (Fig. 2). The single isolate from Colorado was from decayed wood of a $P$. ponderosa killed by fire 4 years earlier; there was no evidence that the tree had been infected while alive.

The 11 collections from Abies and Picea spp. had the same ITS sequence, which differed only slightly from three isolates of $H$. parviporum from Abies spp. in Washington, California, and Mexico (Fig. 1). The latter three isolates were shown to be $H$. parviporum based on pairing studies, ITS and IGS rDNA sequences, and man- 
ganese peroxidase sequences $(5,6,14)$. The branch joining the American isolates of $H$. parviporum had moderate bootstrap support $(80 \%)$, and this branch was sister to the branch containing the Eurasian isolates of $H$. parviporum and $H$. abietinum.

$H$. parviporum was found on Abies concolor and on one Picea engelmannii in a mixed conifer stand with $A$. concolor. It was found in southern Colorado and New Mexico (Fig. 2). We found no evidence of the disease in our survey of 231 stands in Wyoming and 32 stands in the Black Hills, South Dakota. Similarly, in routine activities and surveys in $P$. engelmannii-A. bifolia forests of Colorado, we have not found evidence of the disease.

\section{DISCUSSION}

The Pinus plantations in which $H$. annosum was found in the Nebraska National Forest are associated with the Charles E. Bessey Tree Nursery, the oldest nursery managed by the U.S. Forest Service. Annosus root disease was first found in those plantations on Pinus banksiana in 1964 (19) and is known from only a few stands in the Bessey Ranger District. The plantation where it was found had been established with seedlings from the Nursery in 1911 and thinned in 1930. There were no Pinus forests in the area earlier but J. virginiana, also a host of $H$. annosum, is native to the area. The pathogen may have been native to the area on J. virginiana, or thinning stumps may have become infected by spores blown from long distances. Both $P$. ponderosa and $P$. banksiana were infected there but we did not obtain rDNA sequences of isolates from $P$. banksiana. However, the sequenced sample from $J$. virginiana was from a tree in an infection center with mortality of $P$. banksiana.

If $H$. annosum colonized Pinus plantations in Nebraska, it is curious that it has not been found in the Black Hills, which is dominated by $P$. ponderosa. The first commercial timber sale on federal land in the United States was authorized in the Black Hills in 1898, and continued timber management in the 20th century created abundant stumps, the primary route through which the pathogen establishes new disease centers in Pinus spp. However, the fungus apparently has not become established there. Similarly, aside from the isolate from a fire-killed $P$. ponderosa tree, there is no evidence that $H$. annosum is established in Colorado. Perhaps the dry climates characterizing $P$. ponderosa forests of these regions, or the lack of particular hosts supporting production of large basidiomes, do not allow sufficient basidiospore production for successful establishment.

In Colorado, annosus root disease is common in mixed conifer forests with $A$. concolor, which are restricted to the southern part of the state (Fig. 2). The disease has probably become more frequent as dominance of $A$. concolor has increased due to fire exclusion (1) and selective harvesting of $P$. ponderosa and Pseudotsuga menziesii. In addition to the forests where we collected $H$. parviporum, the disease occurs in A. concolor in the southwest Sangre de Cristo Mountains (Rio Grande National Forest) and the Wet Mountains (San Isabel National Forest) $(8,9)$. Heterobasidion spp. were first found in Colorado in 1909 in Picea engelmannii, near Cripple Creek, on or near the Pike National Forest (18), within the range of A. concolor. Annosus root disease of Pseudotsuga menziesii was reported on the Southern Ute Indian Reservation in Colorado (17), also in association with $A$. concolor. Likewise, the disease has been found in A. bifolia (=A. lasiocarpa in part) within the range of $A$. concolor in Colorado $(10,11)$. In contrast, the disease has not been reported in the extensive Picea engelmannii-A. bifolia forests of Colorado and Wyoming where A. concolor is not present. Annosus root disease occurs in $P$. engelmannii-A. bifolia forests in neighboring New Mexico (23) and Utah (F. A. Baker, personal communication) but $A$. concolor is widely distributed throughout those states. Annosus root disease has not been reported from Pinus ponderosa forests of Colorado, although it is a host in New Mexico, Arizona, and Utah (21,23; Fig. 2). However, we did obtain one isolate in Colorado from a firekilled $P$. ponderosa, with no evidence that the tree had been infected while living. Thus, annosus root disease occurs virtually throughout the range of white fir in southern Colorado but has not been found elsewhere in the state or in $P$. ponderosa.

Annosus root disease is broadly distributed in coniferous forests of Arizona and New Mexico (Fig. 2), with a host range that includes A. concolor, A. bifolia, Picea engelmannii, and Pinus ponderosa (15). In addition to the locations for $H$. parviporum reported here, annosus root disease in $A$. concolor has been observed on the Coconino and Kaibab National Forests in northern Arizona (M. L. Fairweather, unpublished observation), Coronado National Forest in southern Arizona (3), Apache National Forest (23) and White Mountain Apache Reservation (M. L. Fairweather, unpublished observation) in eastern Arizona, Lincoln National Forest in southern New Mexico (4), and forests in northern New Mexico (23). It has been observed in Picea-Abies forests of Arizona on Picea engelmannii on the Kaibab National Forest (23), White Mountain Apache Reservation (M. L. Fairweather, unpublished observation), and Apache National Forest (where it also infects $A$. bifolia; 7), as well as on northern New Mexico forests (23). Anno-

Table 1. Locations, hosts, and identification of collections based on internal transcribed spacer ribosomal DNA sequences

\begin{tabular}{|c|c|c|c|}
\hline $\begin{array}{l}\text { Identified } \\
\text { Heterobasidion spp. }\end{array}$ & Host & $\begin{array}{c}\text { Isolate or } \\
\text { collection no. }\end{array}$ & Location $^{\text {b }}$ \\
\hline Heterobasidion annosum & Juniperus virginiana & B1451 & $6 \mathrm{~km}$ south of Bessey Nursery, Nebraska NF, Nebraska \\
\hline H. annosum & Pinus ponderosa & B1445 & $1 \mathrm{~km}$ south of Bessey Nursery, Nebraska NF, Nebraska \\
\hline H. annosum & P. ponderosa & B1446 & $1 \mathrm{~km}$ south of Bessey Nursery, Nebraska NF, Nebraska \\
\hline H. апповит & P. ponderosa & B1447 & $1 \mathrm{~km}$ south of Bessey Nursery, Nebraska NF, Nebraska \\
\hline H. annosum & P. ponderosa & B1448 & $\begin{array}{l}13 \mathrm{~km} \text { northwest of Flagstaff on the west side of San Francisco Peaks, } \\
\text { Coconino NF, Arizona }\end{array}$ \\
\hline H. annosum & P. ponderosa & B1469 & $14 \mathrm{~km}$ northeast of Nucla, near Forest Road 503, Uncompahgre NF, Colorado \\
\hline H. апnоsum & P. ponderosa & WT.B.PP & $8 \mathrm{~km}$ south of Ruidoso, Mescalero Apache Reservation, New Mexico \\
\hline H. parviporum & Abies concolor & B1436 & Angel Creek Campsites, Uncompahgre NF, Colorado \\
\hline H. parviporum & A. concolor & B1437 & Angel Creek Campsites, Uncompahgre NF, Colorado \\
\hline H. parviporum & A. concolor & B1438 & Amphitheater Campground, Uncompahgre NF, Colorado \\
\hline H. parviporum & A. concolor & B1439 & Amphitheater Campground, Uncompahgre NF, Colorado \\
\hline H. parviporum & A. concolor & B1440 & Vallecito Reservoir, San Juan NF, Colorado \\
\hline H. parviporum & A. concolor & B1441 & Vallecito Reservoir, San Juan NF, Colorado \\
\hline H. parviporum & A. concolor & B1443 & Wolf Creek Campground, San Juan NF, Colorado \\
\hline H. parviporum & A. concolor & B1444 & Wolf Creek Campground, San Juan NF, Colorado \\
\hline H. parviporum & A. concolor & JM2 & $8 \mathrm{~km}$ north of Jemez Springs, Santa Fe NF, New Mexico \\
\hline H. parviporum & A. concolor & SM1 & $16 \mathrm{~km}$ northeast of Albuquerque, Cibola NF, New Mexico \\
\hline H. parviporum & Picea engelmannii & B1442 & Wolf Creek Campground, San Juan NF, Colorado \\
\hline
\end{tabular}

${ }^{a}$ Collection numbers beginning with a B designate cultures maintained at Iowa State University. Other collection numbers designate basidiomes from which DNA was extracted for identification.

${ }^{\mathrm{b}} \mathrm{NF}=$ National Forest. 
sus root disease on Pinus ponderosa is uncommon in Arizona and New Mexico and occurs in widely distributed but localized populations. In addition to the locations where we found $H$. annosum, infected $P$. ponderosa have been observed in Arizona on the Apache-Sitgreaves (M. L. Fairweather, unpublished observation) and Coconino National Forests $(15,23)$ in the east and north, the Williams Ranger District of the Kaibab National Forest (23) in the north, and on the San Carlos Apache Reservation in the southeast (M. L. Fairweather unpublished observation). In New Mexico, the disease occurs on $P$. ponderosa on the Lincoln National Forest and adjoining Mescalero Apache Reservation in the south (13) and on forests in the north (23).

The apparently limited distribution and host range of annosus root disease in
Wyoming, South Dakota, and Colorado contrasts with that in Utah, Nevada, and southern Idaho, where the disease is generally widespread and has been found on every conifer species except $P$. flexilis, $P$. albicaulis, and Larix occidentalis (21). For example, the disease is widespread in Pinus spp. in southern Utah, including the Abajo Mountains in the east near the Colorado border (Fig. 2). In several locations, including the Dixie National Forest in southern Utah and the Toiyabe National Forest near the California-Nevada border, both Pinus spp. and A. concolor were being killed. A study of the species of Heterobasidion involved in such situations would improve understanding of potential host ranges of the respective species.

Although our sample size was not large, the apparent lack of overlap in host range between the two species of Heterobasidion has implications for management in this area. Where substitution of tree species from the two host groups is feasible, it should lead to much less disease in future stands. For example, disease caused by $H$. parviporum in stands of $A$. concolor could be managed by conversion to $P$. ponderosa.

\section{ACKNOWLEDGMENTS}

We thank F. A. Baker, W. R. Jacobi, R. A. Mask, D. M. Rizzo, and C. G. Shaw III for helpful reviews prior to submission of the manuscript; and S. B. Hartvigsen and D. Crawford for providing helpful input on the ecology of Abies concolor in Colorado.

\section{LITERATURE CITED}

1. Fulé, P. Z., Covington, W. W., and Moore, M. M. 1997. Determining reference conditions for ecosystem management of southwestern ponderosa pine forests. Ecol. Appl. 7:895-908.

2. Gardes, M., and Bruns, T. D. 1993 . ITS prim-

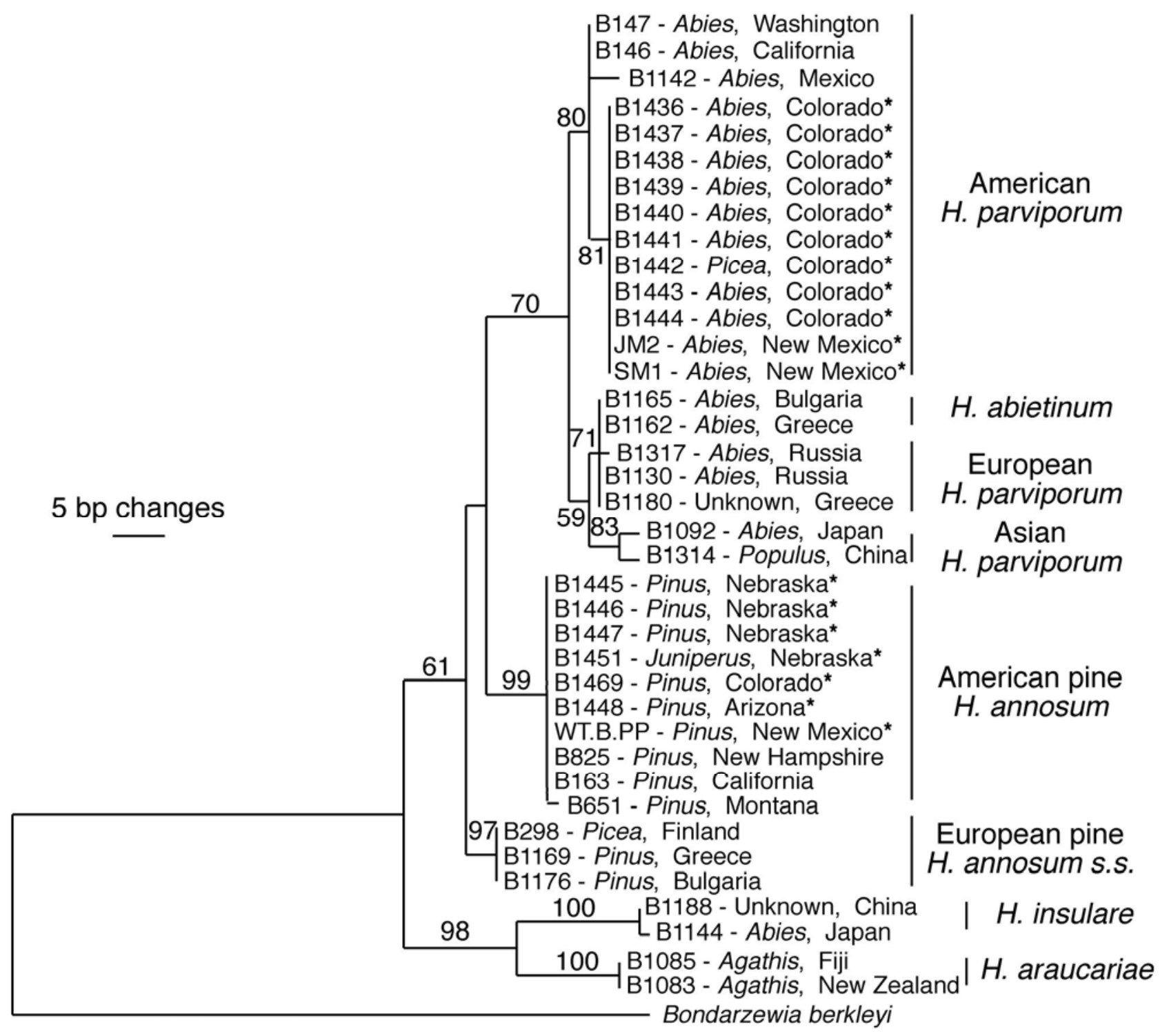

Fig. 1. Single most-parsimonious tree of internal transcribed spacer ribosomal DNA sequences of Heterobasidion spp. Sequences from cultures and basidiomes collected for this study are followed by an asterisk. There were 589 aligned characters in total, 446 of which were constant, 86 were parsimony uninformative, and 57 were parsimony informative. The tree was rooted to Bondarzewia berkeleyi. The tree length was 178 steps, the consistency index was 0.8989 , the retention index was 0.9449 , and the rescaled consistency index was 0.8492 . Bootstrap values greater than $50 \%$ are shown above or below the branches. 


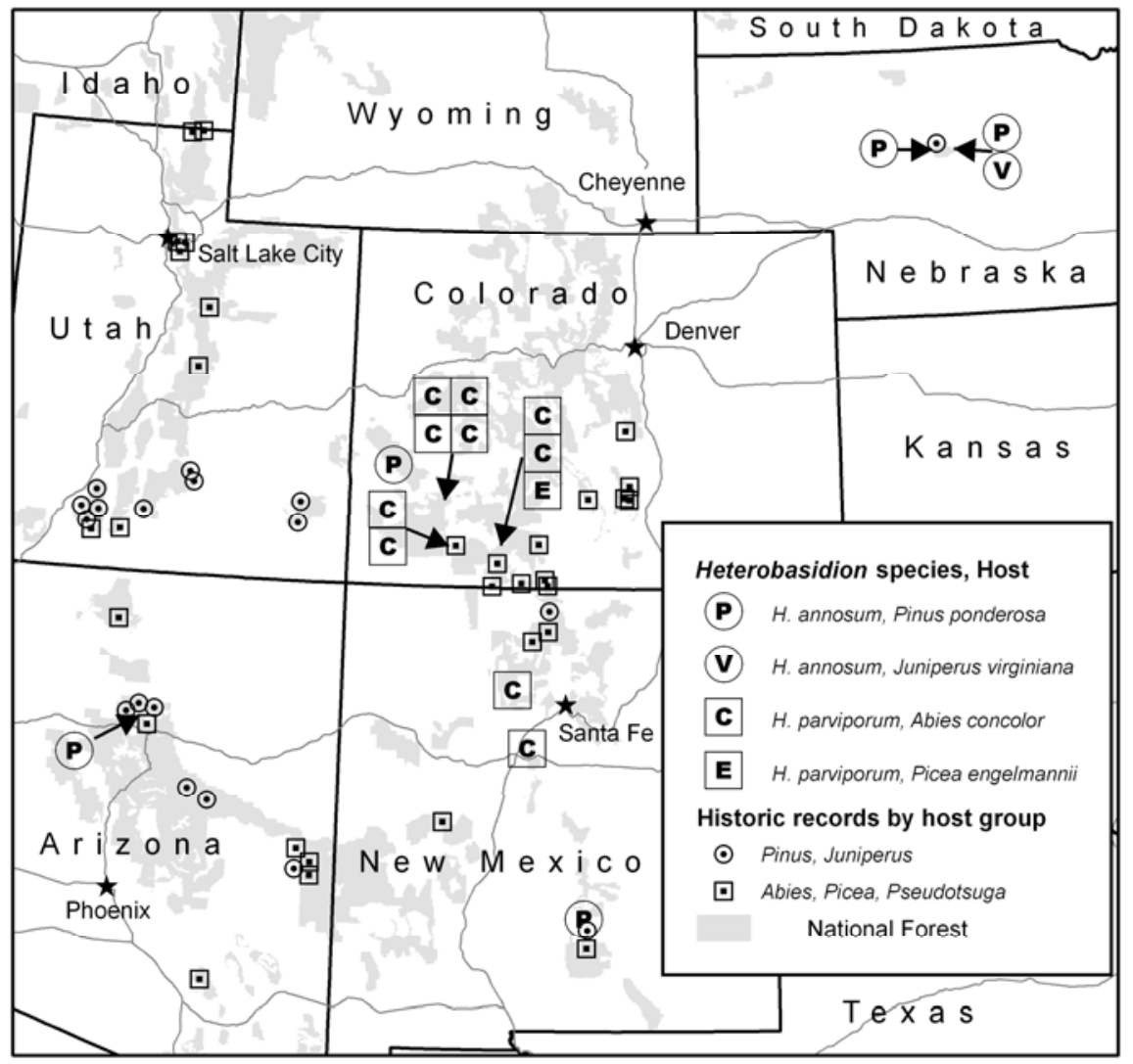

Fig. 2. Hosts and locations of Heterobasidion cultures and specimens identified from Nebraska, Colorado, Arizona, and New Mexico. Historical records for these states and Utah are also included, showing reported host group. We found no record of Heterobasidion spp. from Wyoming or South Dakota.

ers with enhanced specificity for basidiomycetes-application to the identification of mycorrhizae and rusts. Mol. Ecol. 2:113-118.

3. Gilbertson, R. L. 1974. Fungi That Decay Ponderosa Pine. The University of Arizona Press, Tucson.

4. Gilbertson, R. L., Burdsall, H. H., Jr., and Larsen, M. J. 1975. Notes on wood-rotting hymenomycetes in New Mexico. Southwest. Nat. 19:347-360.

5. Harrington, T. C., Stenlid, J., and Korhonen, K. 1998. Evolution in the genus Heterobasidion. Pages 63-74 in: Root and Butt Rots of Forest Trees: Proc. 9th Int. Conf. Root and Butt Rot. C. Delatour, J. J. Guillamin, B. Lung-Escarmant, and B. Marçais, eds. INRAEditions, Paris.

6. Harrington, T. C., Worrall, J. J., and Rizzo, D. M. 1989. Compatibility among host- and Grand Mesa National Forests in Colorado. Biological Evaluation R2-80-4. Forest Insect and Disease Management, State and Private Forestry, Rocky Mountain Region, U.S. Dep. Agric. For. Serv., Lakewood, CO.

11. James, R. L., and Goheen, D. J. 1981. Conifer mortality associated with root diseases and insects in Colorado. Plant Dis. 65:506-507.

12. Johnson, D. W. 1984. An assessment of root diseases in the Rocky Mountain Region. Technical Report R2-29. Rocky Mountain Region, U.S. Dep. Agric. Forest Service, Lakewood, CO.

13. Livingston, W. H., Mangini, A. C., Kinzer, H. G., and Mielke, M. E. 1983. Association of root diseases and bark beetles (Coleoptera: Scolytidae) with Pinus ponderosa in New Mexico. Plant Dis. 67:674-676.

14. Maijala, P., Harrington, T. C., and Raudaskoski, M. 2003. A peroxidase gene family and gene trees in Heterobasidion and related genera. Mycologia 95:209-221.

15. Mielke, J. L., and Davidson, R. W. 1947. Notes on some western wood-decay fungi. Plant Dis. Rep. 31:27-30.

16. Niemelä, T., and Korhonen, K. 1998. Taxonomy of the genus Heterobasidion. Pages 27-35 in: Heterobasidion annosum, Biology, Ecology, Impact and Control. S. Woodward, J. Stenlid, R. Karjalainen, and A. Hütterman, eds. $\mathrm{CAB}$ International, London.

17. Omdal, D. W., Shaw, C. G., III, and Jacobi, W. R. 2004. Symptom expression in conifers infected with Armillaria ostoyae and Heterobasidion annosum. Can. J. For. Res. 34:12101219

18. Shope, P. F. 1931. The Polyporaceae of Colorado. Ann. Mo. Bot. Gard. 18:287-456.

19. Stewart, J. L. 1965. Fomes annosus found in Nebraska. Plant Dis. Rep. 49:456

20. Swofford, D. L. 1993. PAUP: Phylogenetic Analysis Using Parsimony. Illinois Natural History Survey, Champaign, IL.

21. Tegethoff, A. C. 1973. Known distribution of Fomes annosus in the Intermountain Region. Plant Dis. Rep. 57:407-410.

22. White, T. J., Bruns, T. D., Lee, S., and Taylor, J. 1990. Amplification and direct sequencing of fungal ribosomal RNA genes for phylogenetics. Pages 315-322 in: PCR Protocols: A Guide to Methods and Applications. M. A. Innis, D. H. Gelfand, J. J. Sninsky, and T. J. White, eds. Academic Press, San Diego, CA

23. Wood, R. E. 1983. Mortality caused by root diseases and associated pests on six National Forests in Arizona and New Mexico. Forest Pest Management Report R-3 83-13. U.S. Dep. Agric. For. Serv. Southwestern Region, State and Private Forestry, Forest Pest Management, Albuquerque, NM.

24. Worrall, J. J., Parmeter, J. R., and Cobb, F. W. 1983. Host specialization of Heterobasidion annosum. Phytopathology 73:304-307. 